\title{
Inhibitory Activity of Boesenbergia rotunda (L.) Mansf. Rhizome towards the Expression of Akt and NF-KappaB p65 in Acetic Acid-Induced Wistar Rats
}

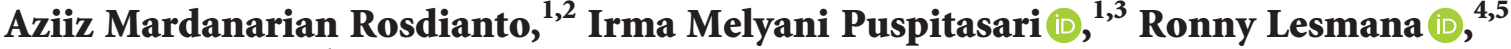 \\ and Jutti Levita $\mathbb{D}^{1}$ \\ ${ }^{1}$ Department of Pharmacology and Clinical Pharmacy, Faculty of Pharmacy, Universitas Padjadjaran, \\ Sumedang 45363, Indonesia \\ ${ }^{2}$ Veterinary Medicine Program, Faculty of Medicine, Universitas Padjadjaran, Sumedang 45363, Indonesia \\ ${ }^{3}$ Center of Excellence in Higher Education for Pharmaceutical Care Innovation, Universitas Padjadjaran, \\ Sumedang 45363, Indonesia \\ ${ }^{4}$ Physiology Molecular Laboratory, Central Laboratory, Universitas Padjadjaran, Sumedang 45363, Indonesia \\ ${ }^{5}$ Department of Medical Basic Sciences, Faculty of Medicine, Universitas Padjadjaran, Sumedang 45363, Indonesia
}

Correspondence should be addressed to Jutti Levita; jutti.levita@unpad.ac.id

Received 7 December 2019; Revised 23 March 2020; Accepted 18 April 2020; Published 20 May 2020

Academic Editor: Ghee T. Tan

Copyright (c) 2020 Aziiz Mardanarian Rosdianto et al. This is an open access article distributed under the Creative Commons Attribution License, which permits unrestricted use, distribution, and reproduction in any medium, provided the original work is properly cited.

\begin{abstract}
Ethnopharmacological Relevance. Boesenbergia rotunda has been traditionally used to reduce stomach discomfort in Indonesia. The objective of the present study was to investigate the anti-inflammatory mechanism and acute toxicity of the ethanol extract of B. rotunda rhizome (BREE) in Wistar rats. Materials and Methods. Forty-eight male Wistar rats were divided into anti-inflammatory mechanism study $(n=18)$ and acute toxicity study $(n=30)$. The anti-inflammatory mechanism study employed six groups $(n=3)$, e.g., the normal control, negative control, positive control (quercetin $20 \mathrm{mg} / \mathrm{kg} \mathrm{BW}$ ), and three doses of BREE $(250 \mathrm{mg} / \mathrm{kg} \mathrm{BW} ; 500 \mathrm{mg} / \mathrm{kg} \mathrm{BW} ; 1000 \mathrm{mg} / \mathrm{kg} \mathrm{BW})$. All groups (except the normal control) were inflammatory-induced i.p. using $0.1 \mathrm{~mL}$ of $1 \%$ of acetic acid. The expression of Akt and NF-kappaB p65 in the stomach and intestine of the rats was examined using Western blot analysis. The acute toxicity study (21 days) was conducted by following the Regulation of Indonesia National Agency of Drug and Food Control No. 7/2014 about In Vivo Nonclinical Toxicity Study using 5 doses of BREE ( $250 \mathrm{mg} / \mathrm{kg} \mathrm{BW;} 500 \mathrm{mg} /$ $\mathrm{kg} \mathrm{BW;} 1000 \mathrm{mg} / \mathrm{kg} \mathrm{BW;} 2000 \mathrm{mg} / \mathrm{kg} \mathrm{BW} ; 000 \mathrm{mg} / \mathrm{kg} \mathrm{BW})$. Results. BREE reduces the infiltration of inflammatory cells in both the stomach and the intestine of acetic acid-induced rats. BREE also alters the expression of Akt and NF-kappaB p65 in the rat's stomach and intestine $(p=0.005)$. The acute toxicity study reveals no lethal effects and behavioral signs of toxicity at all tested doses, which indicates that the $\mathrm{LD}_{50}$ is greater than $4000 \mathrm{mg} / \mathrm{kg} \mathrm{BW}$. Conclusion. Taken together, BREE could inhibit the expression of Akt and NF-kappaB p65 in the stomach and intestine of acetic acid-induced Wistar rats. This plant could be further explored for its potential as plant-based antistomach ulceration.
\end{abstract}

\section{Introduction}

Cornelius Celsus' four cardinal signs of inflammation, rubor et tumor cum calore et dolore, have attracted increasing attention $[1,2]$. Inflammation responses play an important role in multiple diseases with a high prevalence among the population, such as hepatitis [3], lung disease [4], and
Alzheimer's disease [5]. Moreover, they are also centrally related to the pathogenesis of a large number of acute and chronic diseases, i.e., colonic inflammatory response [6] and periodontitis [7].

NF-kappaB is a family of transcription factors that regulates diverse cellular activities related to inflammation and innate and adaptive immune responses [8]. Deregulation of 
NF-kappaB activity is implicated in the development of autoimmune diseases and cancer [9]. NF-kappaB family is composed of five structurally related members, including NFkappaB p50, NF-kappaB p52, RelA (also named p65), RelB, and c-Rel. In most cell types, the p50/p65 heterodimer is sequestered in the cytoplasm by the inhibitor of kappaB (IkappaB), which upon stimulation is phosphorylated resulting in a polyubiquitination and degradation by the $26 \mathrm{~S}$ proteasome. The p65 subunit then translocates into the nucleus, binds to specific NF-kappa B-sites in the enhancer regions of target genes, and regulates transcriptional activity. The activation of NF-kappaB has been observed in the inflamed tissue of the colon of patients with inflammatory bowel disease [10]. Inhibition of NF-kappaB p65 activation correlates with the ability to replace the IkappaB kinase (IKK) activities regulated by protein kinases [11-13]. Protein kinases, e.g., PI3/Akt (a downstream effector of phosphatidylinositol 3-kinase), are necessary for the activation of NFkappaB. Phosphorylation of the p65 subunit (particularly at Ser536 located in the transactivation domain) is important in governing the strength and duration of the NF-kappaBmediated transcriptional response $[14,15]$. Thus, Akt activates IKK for NF-kappaB phosphorylation and improves the transcription ability of NF-kappaB. The Akt pathway is a signal transduction pathway that affects survival and growth in response to extracellular signals. Akt activation mediates downstream responses, including cell survival, growth, proliferation, cell migration, and angiogenesis by phosphorylation of various intracellular proteins [13].

Conventional anti-inflammatory drugs often, if not always, trigger adverse reactions in the body $[14,16,17]$; therefore, researches on plant-derived medicines have increased significantly [18]. Considering this, Boesenbergia rotunda (L.) Mansf. (local name temukunci) [19] could be proposed as a choice, since this plant has been used traditionally to reduce stomach discomforts in Asia, e.g., flatulence and diarrhea $[20,21]$, anti-inflammatory related to periodontitis and cancer [22, 23], anti-inflammatory $[24,25]$, and wound healing [26].

In this study, we investigated the mechanism of $B$. rotunda rhizome in modulating Akt and NF-kappaB p65 in the stomach and intestine of acetic acid-induced Wistar rats. Acetic acid 1\% was chosen as the ulcer-inducer because the damage it causes is similar to that of human ulcers. It was reported that mucosal surface damage had occurred at 30 minutes postinjection of a single dose of acetic acid solution into the gastric mucosal layer of rats [27].

\section{Materials and Methods}

2.1. Plant Materials. The B. rotunda plants and rhizomes were purchased from the Research Institute for Spices and Medicinal Plants (BALITTRO) Manoko Lembang, West Java, Indonesia (http://balittro.litbang.pertanian.go.id/? $\mathrm{p}=993$ \&lang=en). The plant was taxonomically identified by Djoko Kusmoro, a certified biologist at the Laboratory of Plant Taxonomy, Department of Biology, Faculty of Mathematics and Natural Sciences, Universitas Padjadjaran, Indonesia (Document No. 450/HB/10/2017).
2.2. Chemicals. Chemicals used were glacial acetic acid $\geq 99.85 \%$ (CAS Number 64-19-7, Merck) diluted with distilled water to obtain 1\% v/v, ponceau S stain, Akt (44-609G, ThermoFisher Scientific, Israel), a mouse monoclonal IgG1 (kappa light chain) NF-kappaB p65 antibody (Santacruz Biotechnology Inc.), anti-mouse HRP antibody, and substrate (Li-Cor ${ }^{\circledR}$ chemiluminescence), glyceraldehyde-3phosphate dehydrogenase (GAPDH) (Thermo Scientific AM4300, Cell Signaling Co., Ltd.), hematoxylin and eosin (H\&E) (Sigma-Aldrich, Saint-Louis, USA).

2.3. Instruments. Instruments used were evaporator Rotavapor R215, heating bath B-491, vacuum pump V-700, distillation chiller B-741, evaporator glass-ware (Büchi, Flawil, Switzerland), chemical glass-wares (Iwaki pyrex), multimode reader Infinite M200Pro (Tecan, Grodig, Austria), digital analytical balance (Mettler-Toledo, Ohio, USA), microtubes $1.5 \mathrm{~mL}$ (Eppendorf, Wien, Austria), conical centrifuge tubes $50 \mathrm{~mL}$ (Nest, San Diego, USA), micropipette (Eppendorf, Wien, Austria), freezer $-20^{\circ} \mathrm{C}$ (DFX40040, Marietta, OH), cold centrifuge Eppendorf AG5424 (Eppendorf, Hamburg, Jerman), pH meter (Mettler-Toledo, Ohio, USA), the cube dry bath TCDB-01 (Clever Scientific Ltd., Triton Park Brownsover Road Swift Valley Rugby Warwickshire, England), rocker shaker (Clever Scientific Ltd., Triton Park, England), GelDoc ${ }^{\mathrm{TM}}$ EZ gel documentation system (Bio-rad, International Bussiness Park, Singapore), and minigel tank (Invitrogen, Thermoscientific, Israel).

2.4. Extraction. The extraction procedure was carried out by adapting the method of Taweechaisupapong et al. and Woo et al.: The rhizomes were sorted, separated from dirt, washed under tap-water, thin-sliced, and sun-dried. $500 \mathrm{~g}$ of the dried ground rhizome of $B$. rotunda was macerated using ethanol $95 \%$ for $24 \mathrm{~h}$ at room temperature $\left(25-26^{\circ} \mathrm{C}\right)$. The macerate was filtered and the residue was remacerated for $2 \times 24 \mathrm{~h}$ $[28,29]$. The macerates were collected and filtered, and the solvent was rotary-evaporated at $45^{\circ} \mathrm{C}$. The viscous $B$. rotunda rhizome ethanol extract (BREE) (yield 17.24\% w/w) was ready for further use.

2.5. Animals. Forty-eight Wistar albino rats, aged 6-8 weeks, weighed 210-240 g, were bred in the Animal Facility of PT. Biofarma, Kolonel Masturi road, Kav. 10, Kertawangi, Cisarua, West Java, 40551, Indonesia (http://maps.app.goo. gl/v7oXn3Dx3Xr633jp9). The animals were strain identified at the Laboratory of Animal Biosystematic and Plant Taxonomy, Department of Biology, Faculty of Mathematics and Natural Sciences, Universitas Padjadjaran, Indonesia (Document No. 197/HB/10/2018). Rats were kept at $24^{\circ} \mathrm{C}$ under a 12-hour light, 12-hour dark cycle (light was turned on from 6 am to $6 \mathrm{pm}$ ), 55\% relative humidity, with food and water ad libitum for 1 week and 18 hours in the Animal Laboratory, Physiology Division, Faculty of Medicine, Universitas Padjadjaran. Animal handling, maintenance, and euthanasia procedures were performed as approved by the Ethics Committee, Faculty of Medicine, Universitas 
Padjadjaran, Indonesia (Document No. 1458/UN6.KEP/EC/ 2018 for the anti-inflammatory study and No. 1236/ UN6.KEP/EC/2019 for the acute toxicity study).

2.6. Anti-Inflammatory Studies of the Ethanol Extract of B. rotunda Rhizome. Eighteen Wistar male rats, 8-10 weeks, weighed $210-240 \mathrm{~g}$ were randomly divided into six groups $(n=3)$ : normal control (was treated with water only), positive control (was inflammation-induced and treated with quercetin $20 \mathrm{mg} / \mathrm{kgBW}$ orally by using oral gavage feeding) [30], negative control (was inflammation-induced and treated with Arabic gum suspension 2\%), and 3 treatment groups (were given BREE dose of $250 \mathrm{mg} / \mathrm{kg} \mathrm{BW}$, $500 \mathrm{mg} / \mathrm{kg} \mathrm{BW}$, and $1000 \mathrm{mg} / \mathrm{kg} \mathrm{BW}$, all diluted in distilled water, respectively. The administration was done by using oral gavage feeding) [31, 32]. $0.1 \mathrm{~mL}$ of acetic acid $1 \%$ in distilled water $(\mathrm{v} / \mathrm{v})$ was injected intraperitoneally as the inflammation inducer by following the procedure of Kolgazi et al. [33] and Ozturk et al. [34] with a few modifications. The acetic acid induction was injected 30 minutes before the treatment. The rats were observed for 18 hours and the total body of each rat was weighed before the sacrifice. The rats were sacrificed using isoflurane $2 \%$ inhalation. The stomach and intestine of each rat were removed, weighed, and were rapidly frozen in liquid nitrogen and stored at $-80^{\circ} \mathrm{C}$ for further use. The ratio of the organ per body of the rats was calculated.

\subsection{Histopathology Analysis: Infiltration of Inflammatory} Cells. The stomach and intestine of the rats were fixed in $10 \% \mathrm{v} / \mathrm{v}$ buffered formalin (contained $0.01 \mathrm{M}$ phosphate buffer saline at $\mathrm{pH} 7.2$ ) and were subsequently sliced to $5 \mu \mathrm{m}$ thickness, embedded in paraffin, and were H\&E stained to evaluate the infiltration of inflammatory cells as described by Cantarella et al. [35] and Cantarella et al. [36]. A light microscope was used for the histopathological assessment by a total magnification of $400 x$ and $1000 x$.

2.8. Western Blot Analysis. The dissected stomach and intestine of the rats were weighed, homogenized in lysis buffer (containing $10 \mathrm{mM}$ Tris- $\mathrm{HCl} \mathrm{pH} 7.8,150 \mathrm{mM} \mathrm{NaCl}, 1 \mathrm{mM}$ EDTA, $1 \%$ Nonidet P-40, and protease inhibitors). The protein samples were heat-denatured at $96^{\circ} \mathrm{C}$ for 5 minutes. Samples $(12 \mu \mathrm{g} / \mathrm{lane})$ were separated by SDS-PAGE and were then transferred to a nitrocellulose membrane (GE Healthcare) for 1 hour at room temperature and blocked overnight at $4^{\circ} \mathrm{C}$ in Tris-buffered saline with $0.1 \%$ Tween ${ }^{\circledR}$ 20. Immunoblotting was performed using a mouse monoclonal IgG1 (kappa light chain) NF-kappaB p65 antibody (Santacruz Biotechnology Inc., diluted 1:100), Akt (ThermoFisher Scientific; diluted 1:10000 in phosphate-buffered saline 0.1\% Tween ${ }^{\circledR} 20$ ), and GAPDH (Santacruz Biotechnology Inc.; diluted $1: 1000)$. The signals were developed using enhanced chemiluminescence reagent (GE Healthcare) and the band intensities were determined using ImageJ software (https://imagej.nih.gov/ij/). Blots were stripped and were reprobed using an anti-GAPDH mouse monoclonal antibody as the internal control to monitor the level of protein.

2.9. Acute Toxicity Study. The acute toxicity study (21 days) was conducted by following the Regulation of Indonesia National Agency of Drug and Food Control No. 7/2014 about In Vivo Nonclinical Toxicity Study using thirty Wistar male rats, $8-10$ weeks, weighing $210-240 \mathrm{~g}$. The rats were randomly divided into six groups $(n=5)$ : normal control (treated with water only), and 5 treatment groups of BREE (250 mg/kg BW; 500 mg/kg BW; 1000 mg/kg BW; 2000 mg/ $\mathrm{kg} \mathrm{BW} ; 4000 \mathrm{mg} / \mathrm{kgBW}$ ) which were given by single administration. The BW of the rats was weighed and their physical changes of toxic effects (color changes of skin and eyes, mucous secretion, urination, defecation, strange behavior, etc.) were observed daily. On day $21^{\text {st }}$ the rats were sacrificed and their main organs (heart, kidney, liver, testis) were examined.

2.10. Statistical Analysis. SPSS 17.0 for Windows was employed to analyze the data. Significant differences between groups were analyzed using the One-Way ANOVA and post hoc Bonferroni test. All data are presented as the mean \pm SEM, and the $p$-value $<0.05$ indicates a significant result.

\section{Results}

The solvent selection is crucial for plant extraction. Ethanol is a polar universal solvent that can extract almost all secondary metabolites in the plants [37]. The presence of flavonol quercetin in the ethanol extract of $B$. rotunda rhizome has been confirmed by employing the liquid chromatography-mass spectrometric method [38]. In this work, Arabic gum was used as the suspending agent. This gum, obtained from the dried exudate of Acacia senegal branches, consists of water-soluble dietary fibers. Arabic gum is commonly used to increase the digestibility of plant extracts in animal studies [39].

3.1. The Ratio of Organ per Body Weight. Figures 1(a) and 1(b) show the influence of BREE on the ratio of stomach/BW and intestine/BW, respectively, of the inflammation-induced rats. No significant difference in the ratio of organ/ BW was observed. However, the negative control group indicated a higher ratio compared to that of other groups.

\subsection{Histopathology Analysis: Infiltration of Inflammatory} Cells. High infiltration of inflammatory cells was observed in the negative control group. BREE could reduce the infiltration of inflammatory cells in both the stomach (Figure 2(a)) and the intestine (Figure 2(b)) of acetic acidinduced rats.

The normal size of the rat's stomach is $2.5 \times 2.5 \mathrm{~cm}^{2}$. An increase of the size is observed in all acetic acid-induced groups, with the exception in the group treated with the highest dose of BREE (Figure 3). Furthermore, the organ 


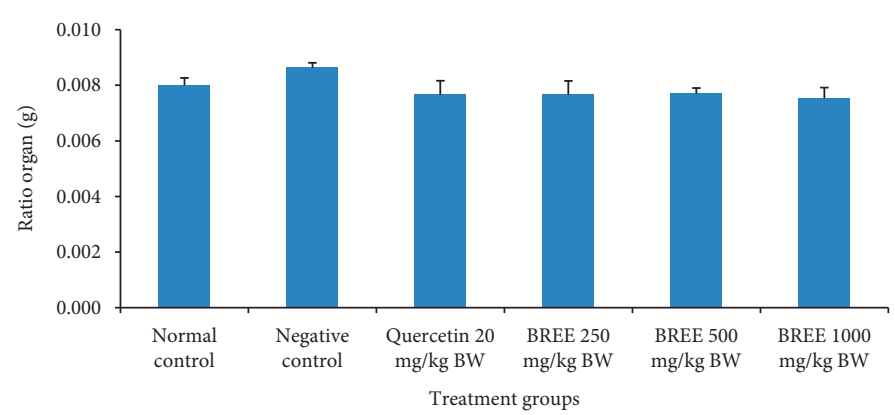

(a)

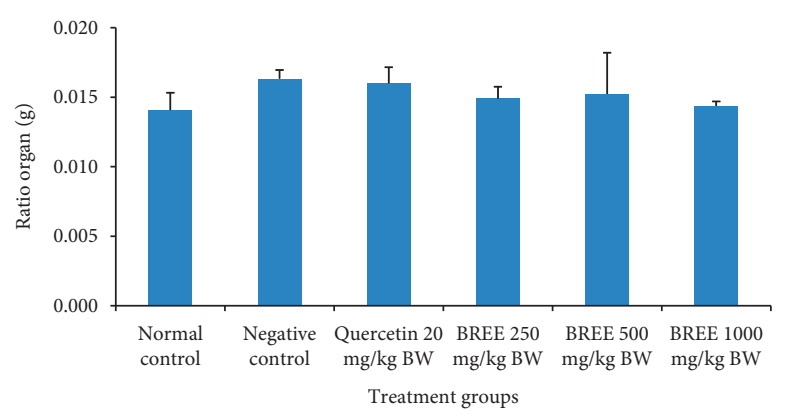

(b)

FIGURE 1: Ratio of (a) stomach/BW and (b) intestine/BW of the rats. The error bars represent the standard error of measurements $(n=3)$.

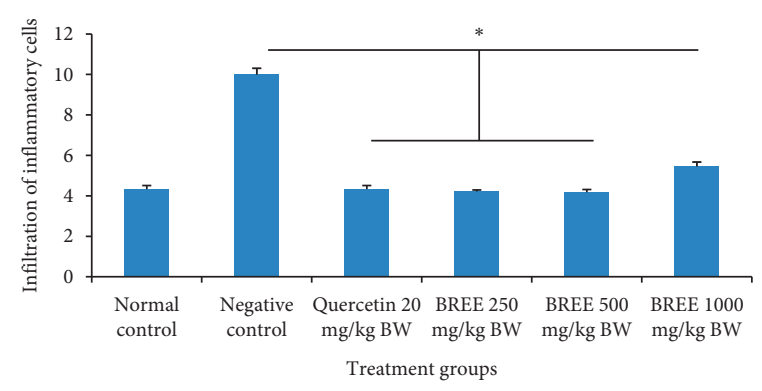

(a)

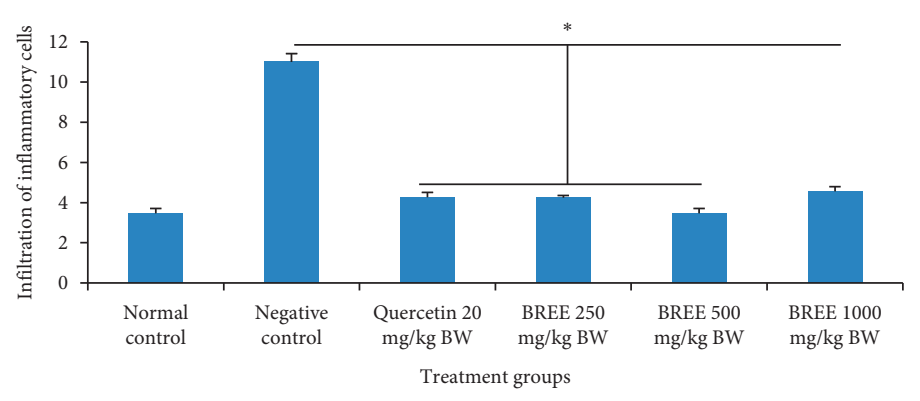

(b)

FIGURE 2: Infiltration of inflammatory cells in the stomach (a) and intestine (b) of acetic acid-induced rats. The error bars represent the standard error of measurements $(n=3) .{ }^{*} p<0.05$ means significantly different compared with the negative control.
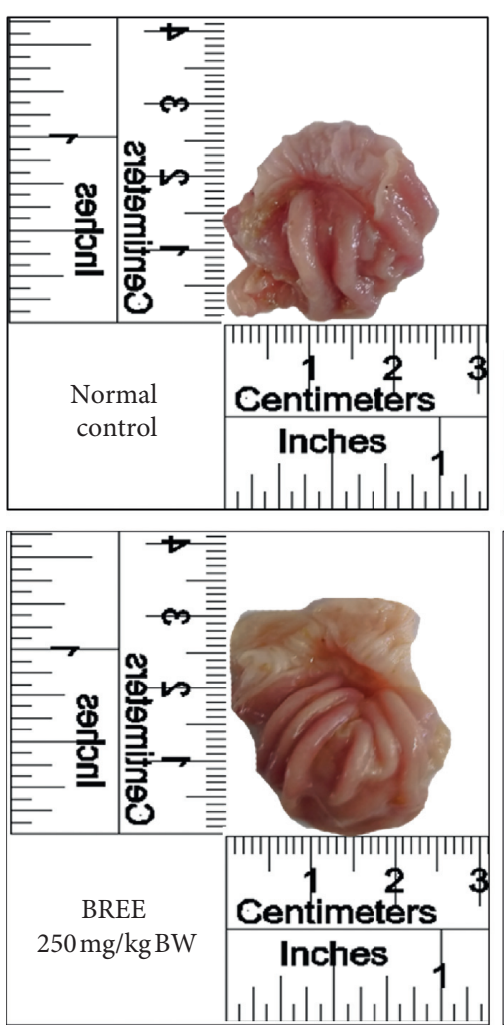
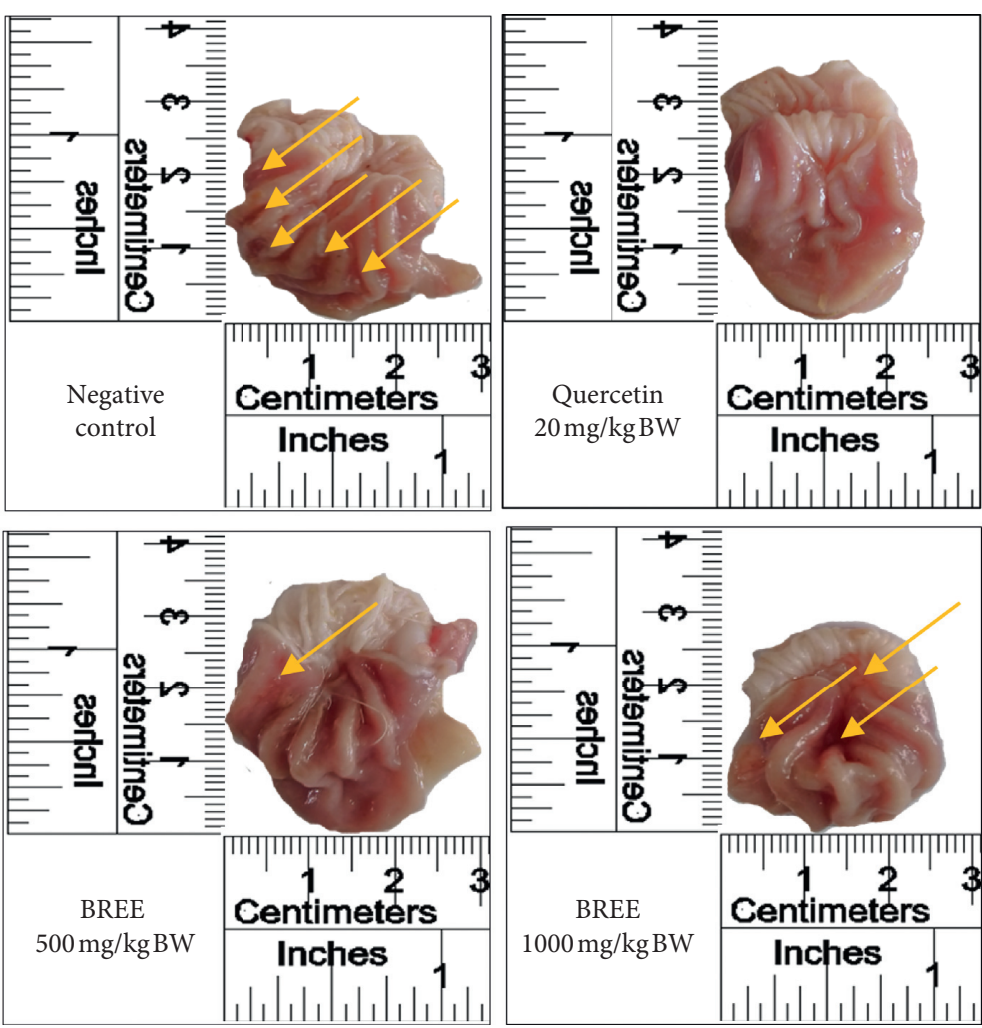

(a)

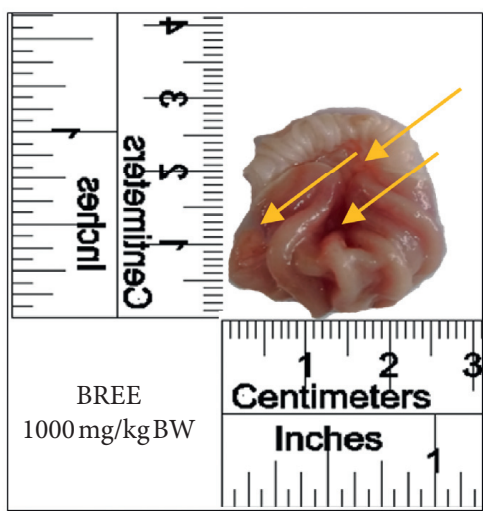

Figure 3: Continued. 

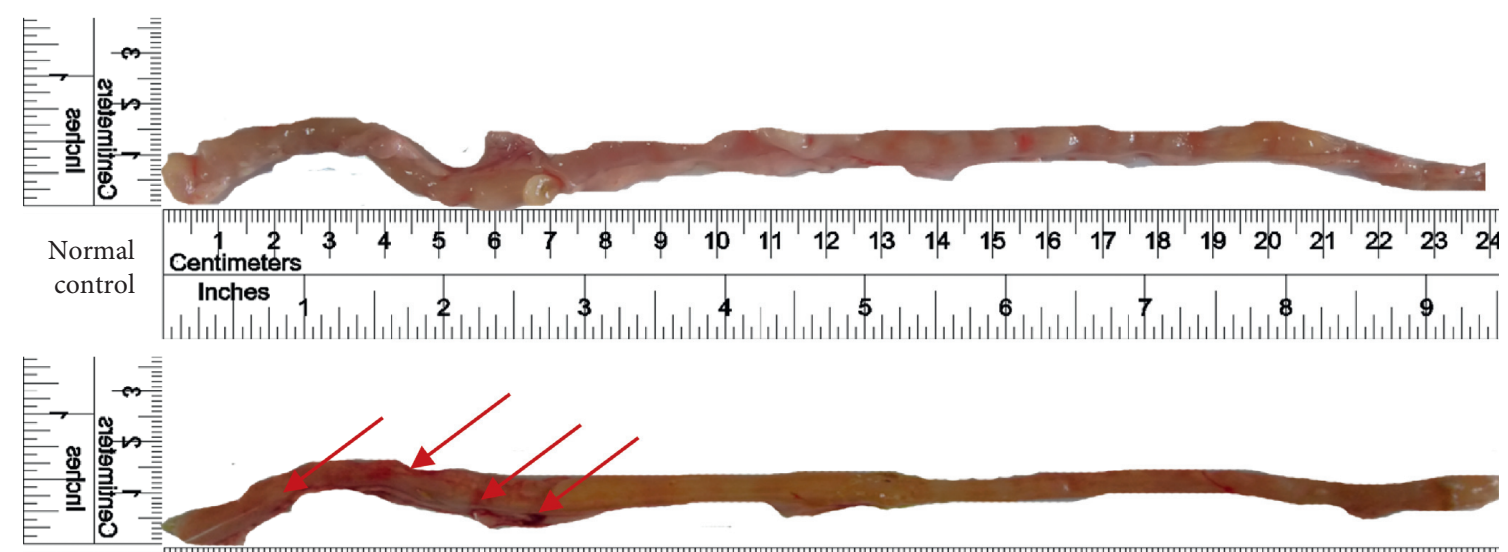

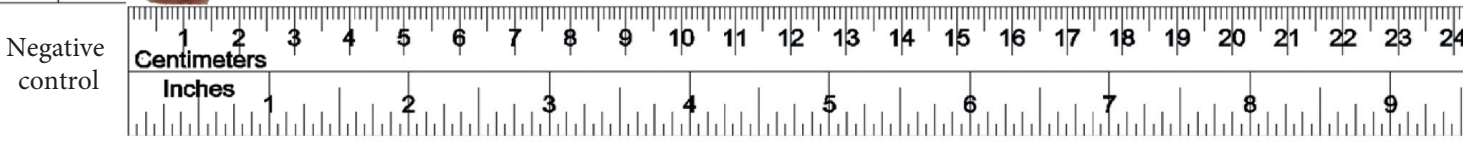

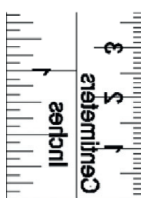

Quercetin $20 \mathrm{mg} / \mathrm{kg}$

BW

पाTा

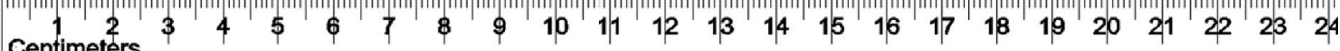

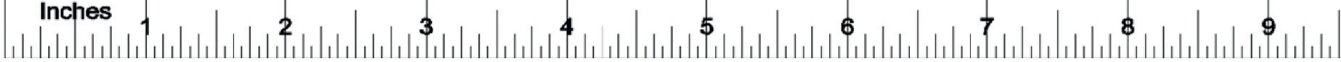
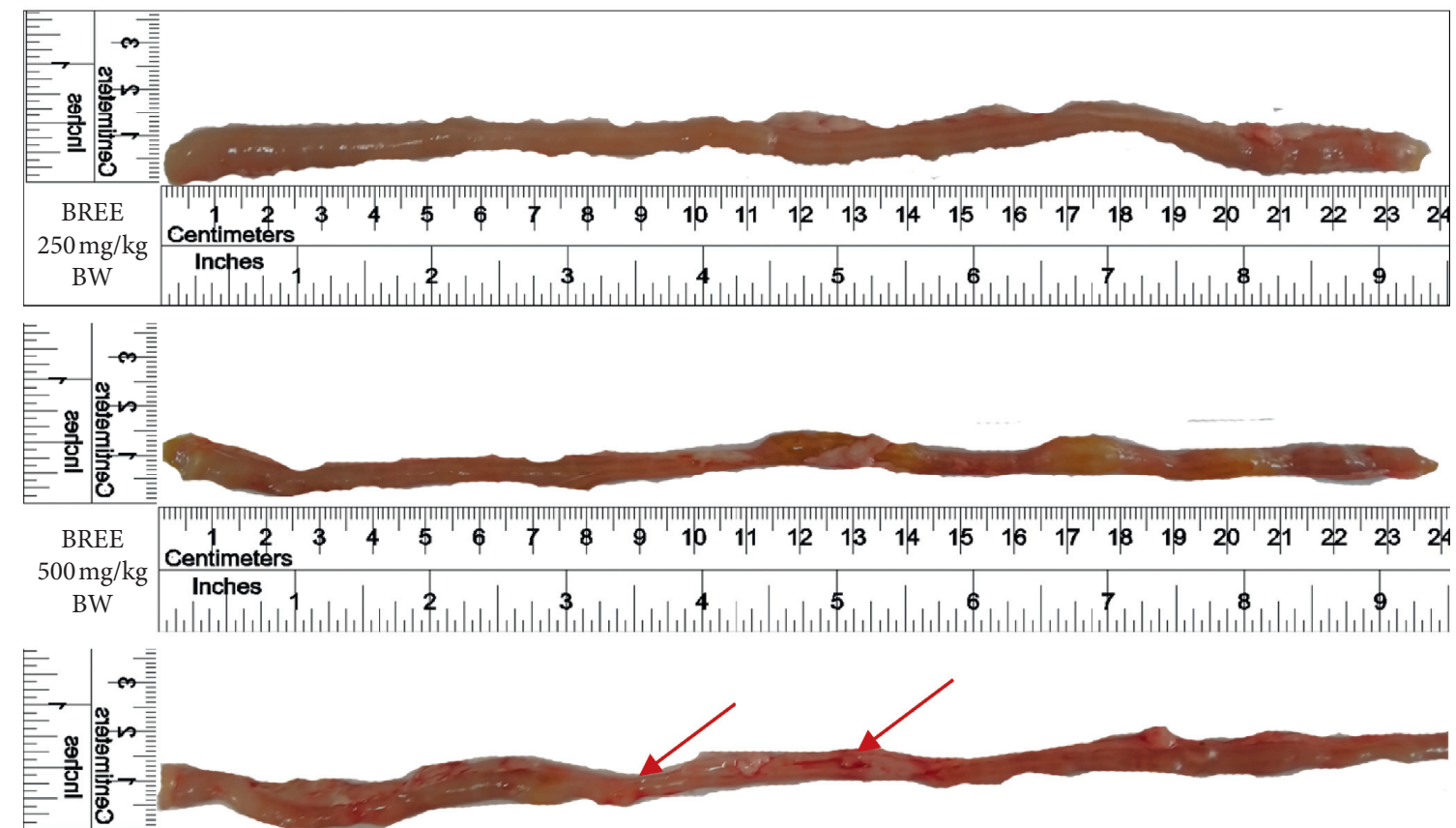

BREE $1000 \mathrm{mg} / \mathrm{kg}$
$\mathrm{BW}$

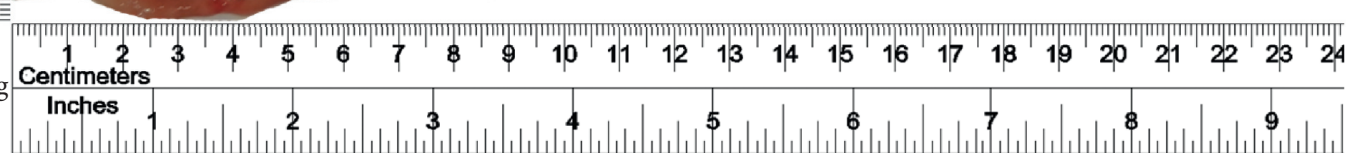

(b)

FIgURE 3: The macroscopic examination of the stomach (a) and intestine (b) of the rats. Ulceration spots were observed on the stomach (indicated by yellow arrows) of the negative control rats and the intestine (indicated by red arrows) of the negative control and BREE dose $1000 \mathrm{mg} / \mathrm{kg} \mathrm{BW}$ rats. 
examination (Figure 3) indicated that ulceration spots were observed on the stomach (yellow arrows) and intestine (red arrows) of the negative control groups. Surprisingly, the highest dose of BREE (1000 mg/kg BW) also elicits ulceration in both the stomach and intestine.

The histopathology of the stomach is presented in Figure 4(a) (H\&E stain, objective lense 4x) and Figure 4(b) (H\&E stain, objective lense 100x). Histopathology of the intestine is presented in Figure 5(a) (H\&E stain, objective lense $4 \mathrm{x}$ ) and Figure 5(b) (H\&E stain, objective lense 100x). An active inflammation indicated by the infiltration of granulocyte neutrophils was observed in the negative control (ulceration index $=1.5$ both in the stomach and intestine) as well as in the rats treated with quercetin (ulceration index $=0.33$ both in the stomach and intestine) and the highest dose of BREE (ulceration index $=1.0$ in the stomach and intestine).

3.3. Western Blot Analysis. Figures 6(a) and 6(b) show the bands of NF-kappaB p65 $(60 \mathrm{kDa})$, Akt $(60 \mathrm{kDa})$, and GAPDH $(37 \mathrm{kDa})$ in the stomach and the intestine of the Wistar rats, respectively. The relative expressions of NFkappaB p65 (Figure 6(a) middle part) and Akt (Figure 6(a) lower part) normalized by GAPDH in the stomach at a dose of $250 \mathrm{mg} / \mathrm{kgBW}$ are $0.64 \pm 0.09$ and $0.68 \pm 0.14$, respectively, whereas a dose of $500 \mathrm{mg} / \mathrm{kg} \mathrm{BW}$ is $0.35 \pm 0.24$ and $0.41 \pm 0.04$, respectively. This inhibitory activity on Akt expression and NF-kappaB p65 is better than that of quercetin (the positive control). However, an increase of this expression was observed at dose $1000 \mathrm{mg} / \mathrm{kg} \mathrm{BW}$ of BREE.

Similarly, the relative expressions of NF-kappaB p65 (Figure 6(b) middle part) and Akt (Figure 6(b) lower part) normalized by GAPDH in the intestine at a dose of $250 \mathrm{mg} /$ $\mathrm{kg} \mathrm{BW}$ are $1.05 \pm 0.30$ and $0.55 \pm 0.27$, respectively, whereas a dose of $500 \mathrm{mg} / \mathrm{kg} \mathrm{BW}$ is $0.56 \pm 0.21$ and $0.43 \pm 0.19$, respectively. This inhibitory activity on Akt expression and NF-kappaB p65 is better than that of quercetin (the positive control). However, an increase of this expression was observed at a dose of $1000 \mathrm{mg} / \mathrm{kg} \mathrm{BW}$ of BREE.

3.4. Acute Toxicity Study (21 Days). During 21 consecutive days of observation after a single oral BREE-administration, the rats did not show any sign of toxicity nor death which indicates that the $\mathrm{LD}_{50}$ of BREE is greater than $4000 \mathrm{mg}$ / $\mathrm{kgBW}$. The general appearance, grooming, posture, behavior of the rats were normal. The BW of the rats was significantly different between D-0 and D-21 of the study (Figure 7), except for the normal control group and rats treated with BREE dose $500 \mathrm{mg} / \mathrm{kg} \mathrm{BW}$. The ratio of organ/ $\mathrm{BW}$ on day $21^{\text {st }}$ is presented in Figure 8.

\section{Discussion}

More than 370 million people representing 5000 distinct groups had received global recognition, namely, the United Nations Declaration on the Rights of Indigenous Peoples (UNDRIP), in which it affirmed the rights of indigenous peoples to their traditional medicines and health practices
[40]. A family survey in Indonesia, which was carried out during 2014-2015, reported that a high prevalence of indigenous medicine was used in children and several social factors and poor health status of its use were identified [41].

The rhizome of Boesenbergia rotunda (local name temukunci) has been used traditionally to reduce stomach discomforts [20, 21]. This plant's anti-inflammatory activity has also been reported [22-26]. Quercetin, a flavonol, has been reported to be contained in the rhizome of this plant [38]. Our work indicated that the ethanol extract of B. rotunda rhizome (BREE) obtained from Lembang, West Java, Indonesia, did not influence the ratio of stomach/BW and intestine/BW of the inflammation-induced rats.

Lower doses of BREE could significantly $(p<0.01)$ reduce the infiltration of inflammatory cells (indicated by the absence of the granulocyte neutrophils) in both the stomach and the intestine of acetic acid-induced rats. The infiltration of granulocyte neutrophils was observed in the stomach and intestine of rats of the negative control group, the positive control group, and rats treated with dose $1000 \mathrm{mg} / \mathrm{kg} \mathrm{BW}$ of BREE (indicated by red arrows in Figures 4(b) and 5(b)). This infiltration of neutrophils indicated an occurrence of inflammation in both organs. Quercetin used in our study (20 mg/kg BW) has caused a slight inflammation in the rat's stomach and intestine. This result is similar to that of Tang et al.; a higher concentration of quercetin $(15.0 \mu \mathrm{g} / \mathrm{ml})$ exposed to RAW264.7 cells for 24 hours that was reported could significantly decrease the cell viability [42].

The granulocyte neutrophils are produced in the bone marrow, and upon activation by various cytokines, they transit via the vascular endothelium during the recruitment process and enter the inflammatory site. Subsequently, they become fully activated as characterized by the release of their granule proteins [43]. These granulocyte neutrophils are also called polymorphonuclear neutrophils or polymorphs [44].

In the Western blot experiment, it was confirmed that the NF-kappaB signaling pathway was activated in the acetic acid-induced rats and yet this pathway was blocked by lower doses of BREE. The doses $250 \mathrm{mg} / \mathrm{kg} \mathrm{BW}$ and $500 \mathrm{mg} / \mathrm{kg} \mathrm{BW}$ of BREE could inhibit the expression of Akt and NF-kappaB p65 in the stomach and intestine of the acetic acid-induced rats better than that of quercetin (the positive control). Akt plays an important role in the activation of NF-kappaB. Thus, the inhibition of Akt expression indirectly inactivates the NF-kappaB and reduces the expression of the p65 subunit. However, an increase of NF-kappaB p65 and Akt expression was observed in rats treated with the highest dose $(1000 \mathrm{mg} / \mathrm{kg} \mathrm{BW})$ of BREE (Figure 6). This result, nonetheless, is in agreement with the macroscopic examination (Figure 3(b)). Figure 3(b) revealed that the highest dose of BREE $(1000 \mathrm{mg} / \mathrm{kg} \mathrm{BW})$ elicits ulceration in the intestine.

A higher concentration of plant extract could induce abnormality in the animal. A previous study on the antiinflammatory activity of Boswellia serrata extract reported that the highest concentration of the extract $(100 \mu \mathrm{g}$ dry extract $/ \mathrm{mL}$ ) was found to be cytotoxic and decreased the viability of porcine aortic endothelial cells, while lower concentrations did not affect the cell viability [45]. 


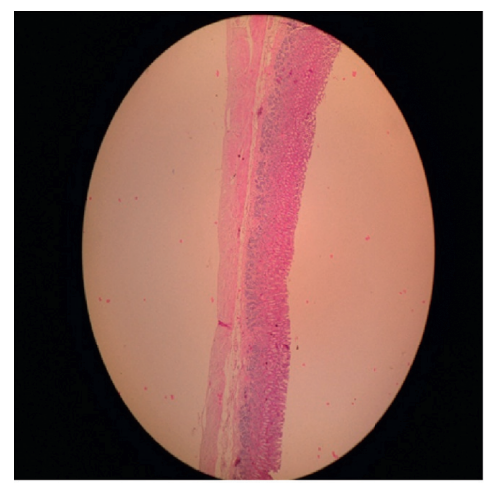

Normal group

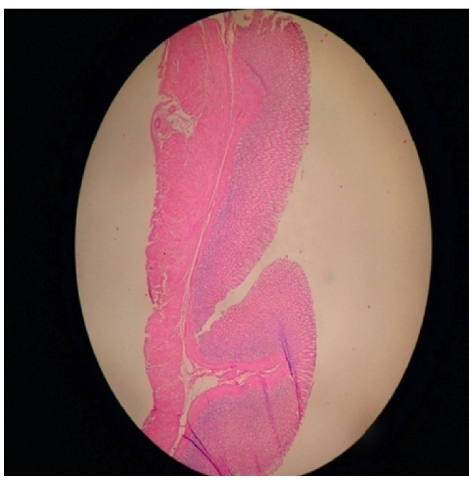

BREE $250 \mathrm{mg} / \mathrm{kg}$ BW

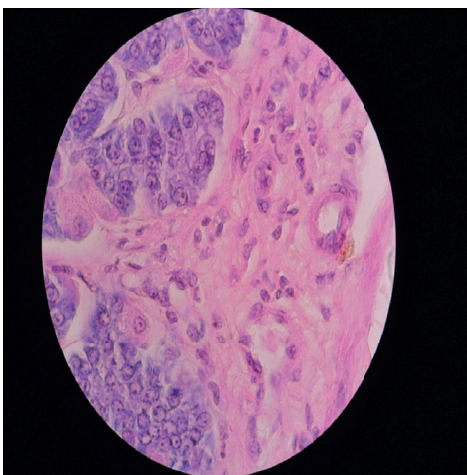

Normal group

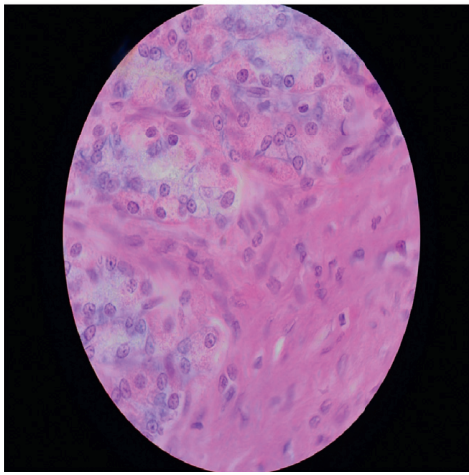

BREE $250 \mathrm{mg} / \mathrm{kg} \mathrm{BW}$

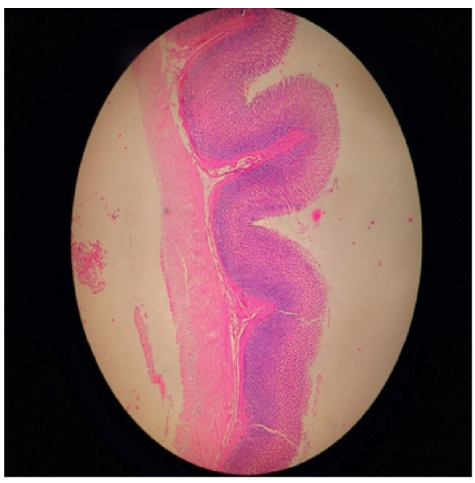

Negative control

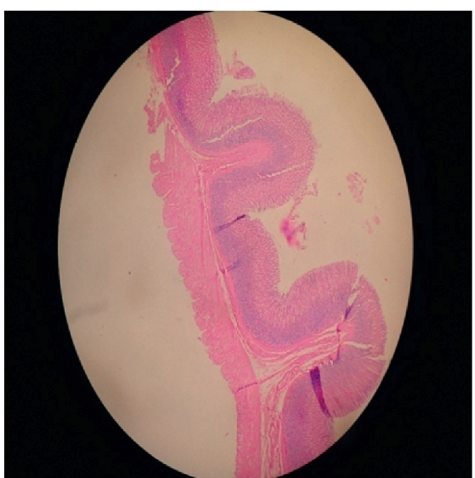

BREE $500 \mathrm{mg} / \mathrm{kg}$ BW

(a)

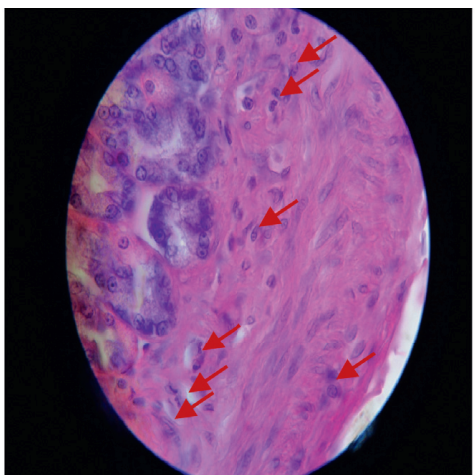

Negative control

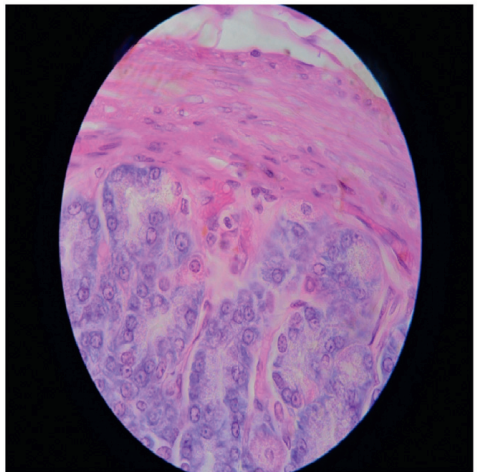

BREE $500 \mathrm{mg} / \mathrm{kg} \mathrm{BW}$

(b)

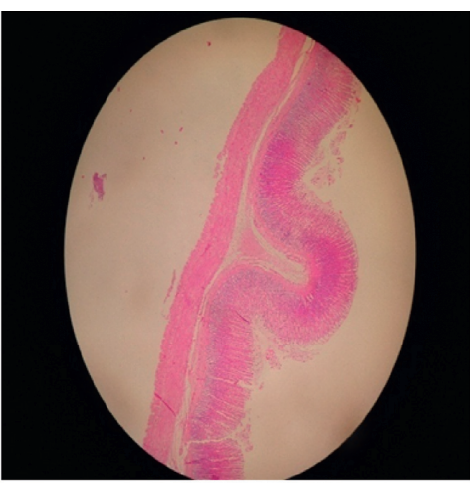

Quercetin 20 mg/kg BW

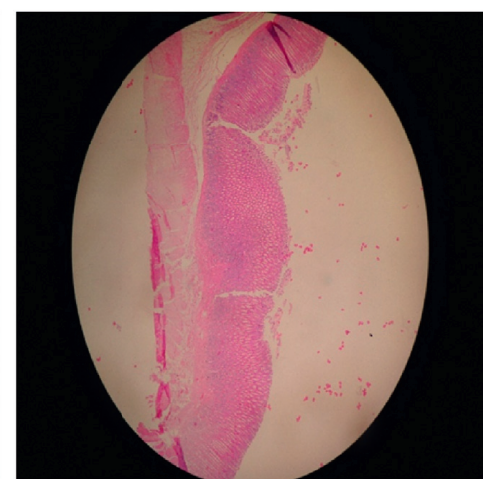

BREE $1000 \mathrm{mg} / \mathrm{kg}$ BW

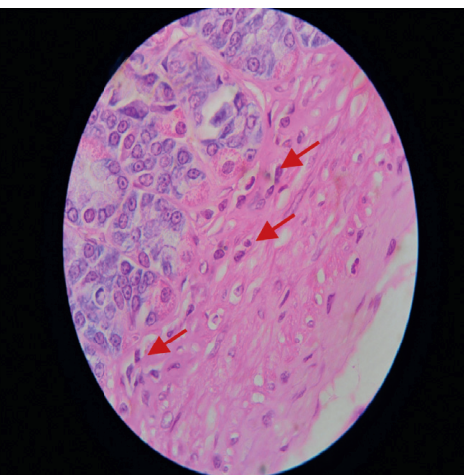

Quercetin 20 mg/kg BW

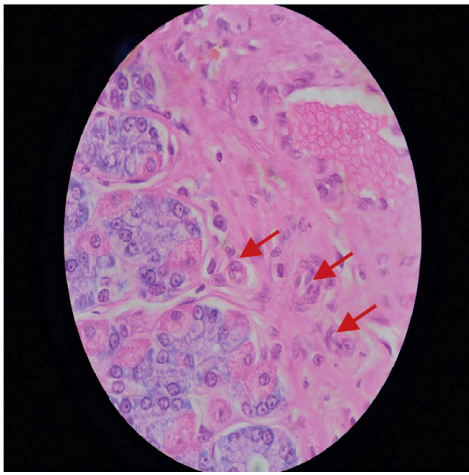

BREE $1000 \mathrm{mg} / \mathrm{kg}$ BW

Figure 4: Microscopic histopathology examination of the stomach of the rats. Objective lens 4x (a) and 100x (b). Red arrows indicate granulocyte neutrophils. 


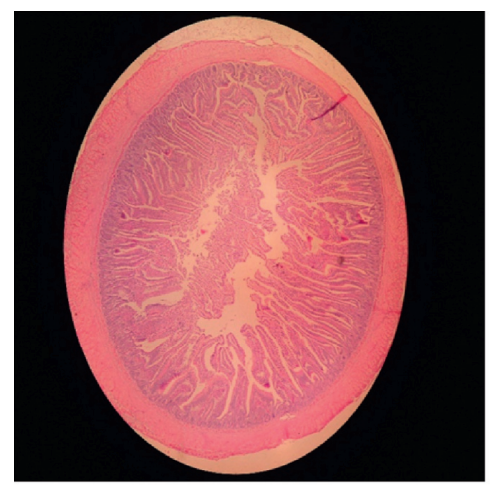

Normal group

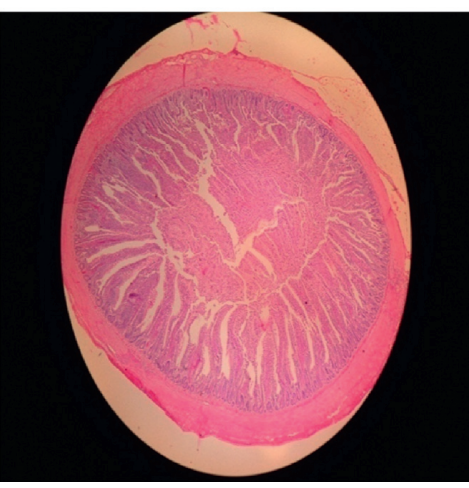

BREE $250 \mathrm{mg} / \mathrm{kg}$ BW

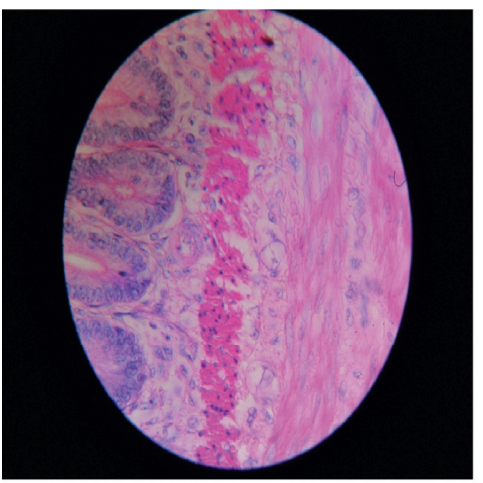

Normal group

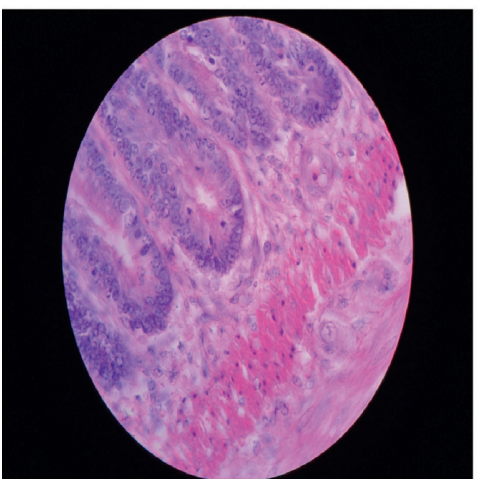

BREE $250 \mathrm{mg} / \mathrm{kg}$ BW

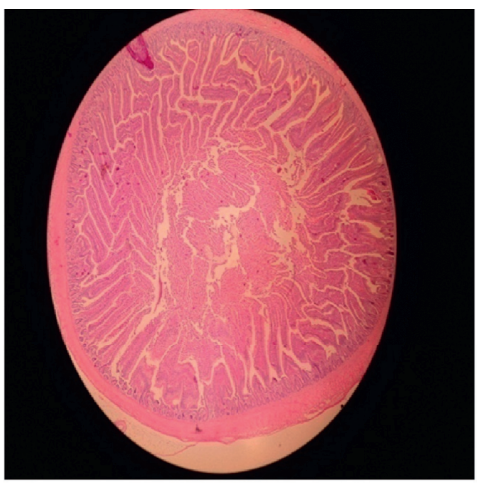

Negative control

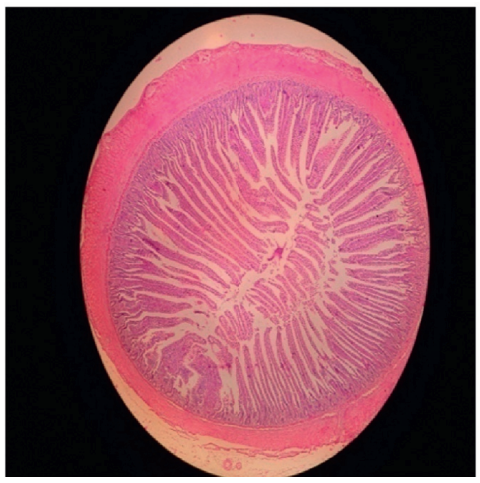

BREE $500 \mathrm{mg} / \mathrm{kg} \mathrm{BW}$

(a)

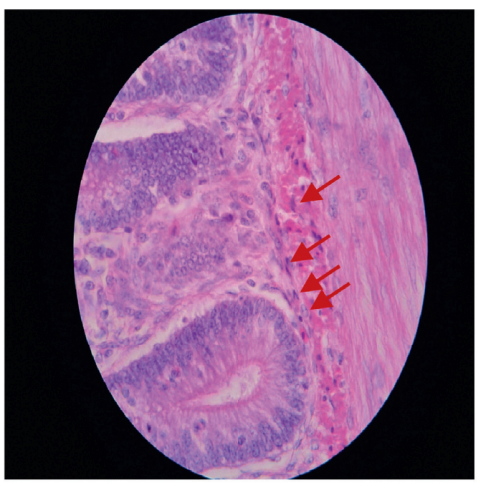

Negative control

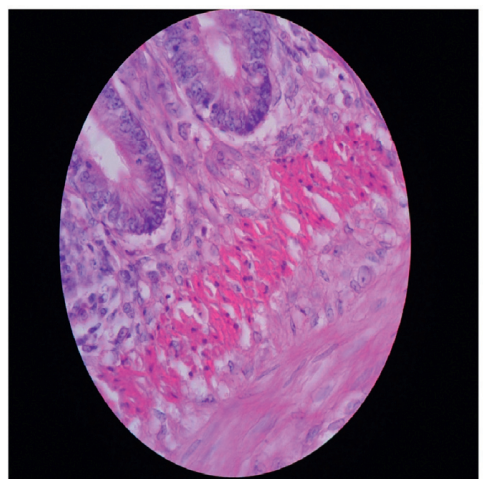

BREE $500 \mathrm{mg} / \mathrm{kg}$ BW

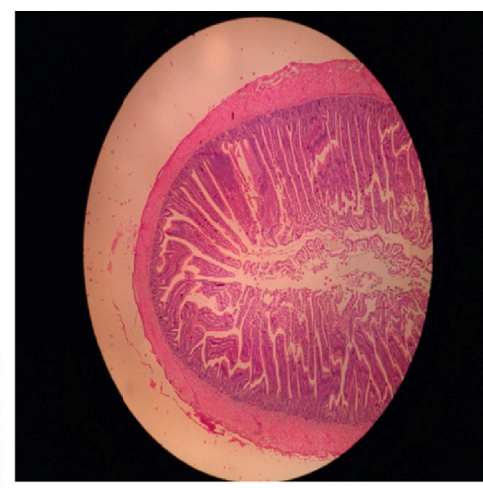

Quercetin 20 mg/kgBW

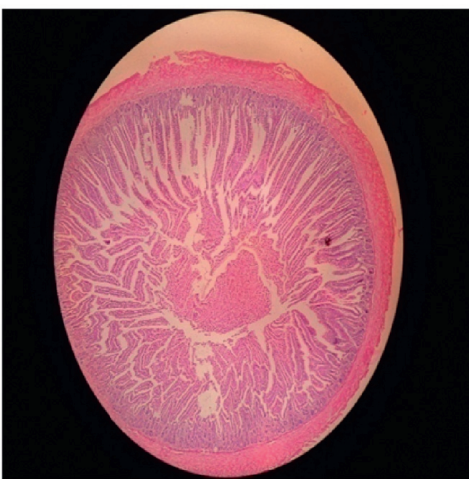

BREE $1000 \mathrm{mg} / \mathrm{kgBW}$

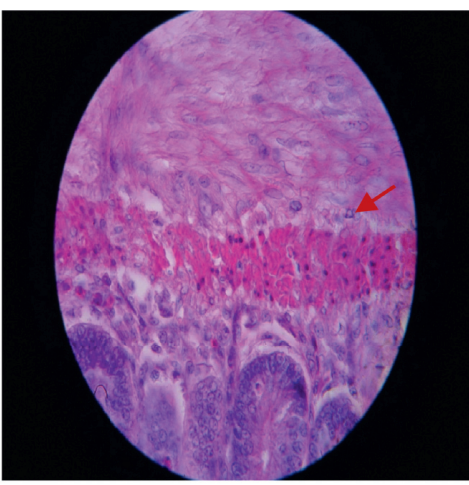

Quercetin 20 mg/kgBW

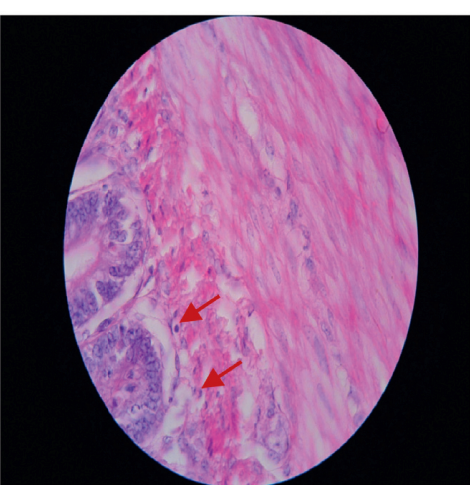

BREE $1000 \mathrm{mg} / \mathrm{kg} \mathrm{BW}$

(b)

Figure 5: Microscopic histopathology examination of the intestine of the rats. Objective lens 4x (a) and 100x (b). Red arrows indicate granulocyte neutrophils. 

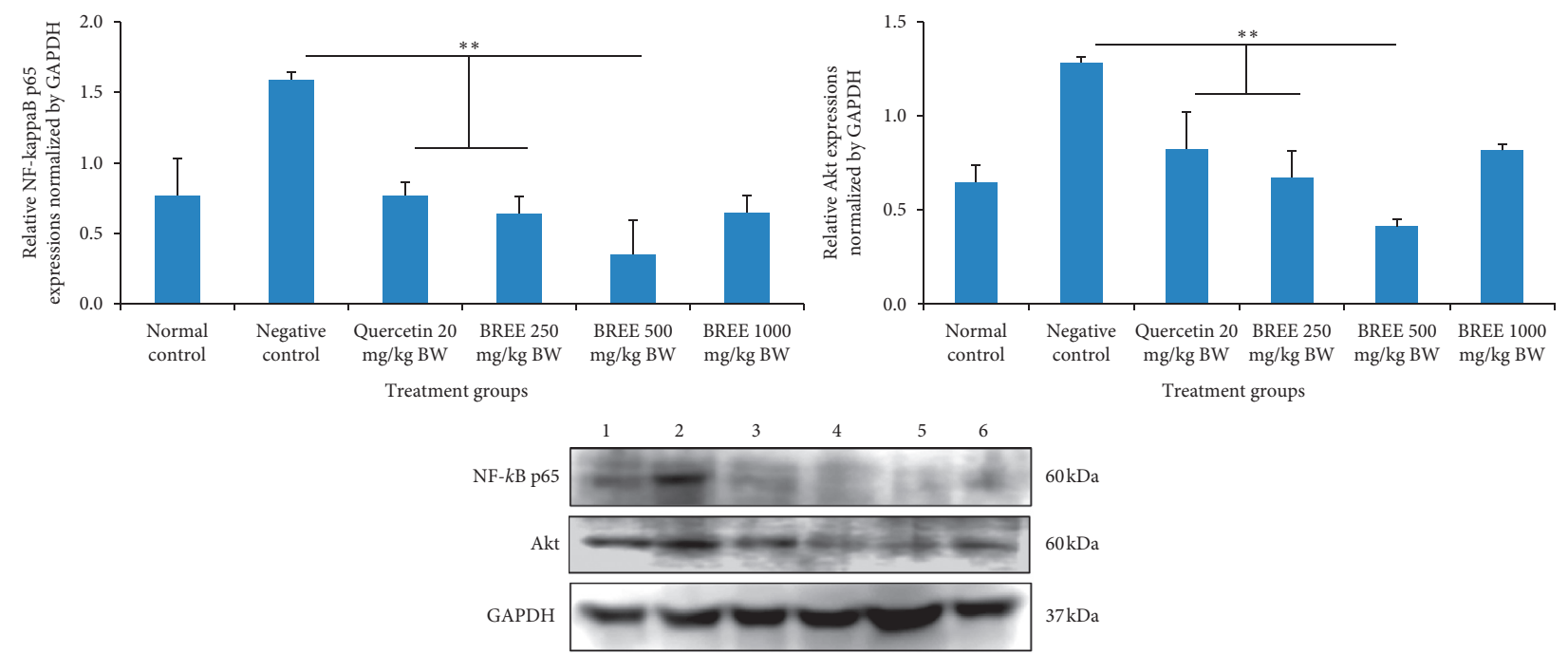

(a)
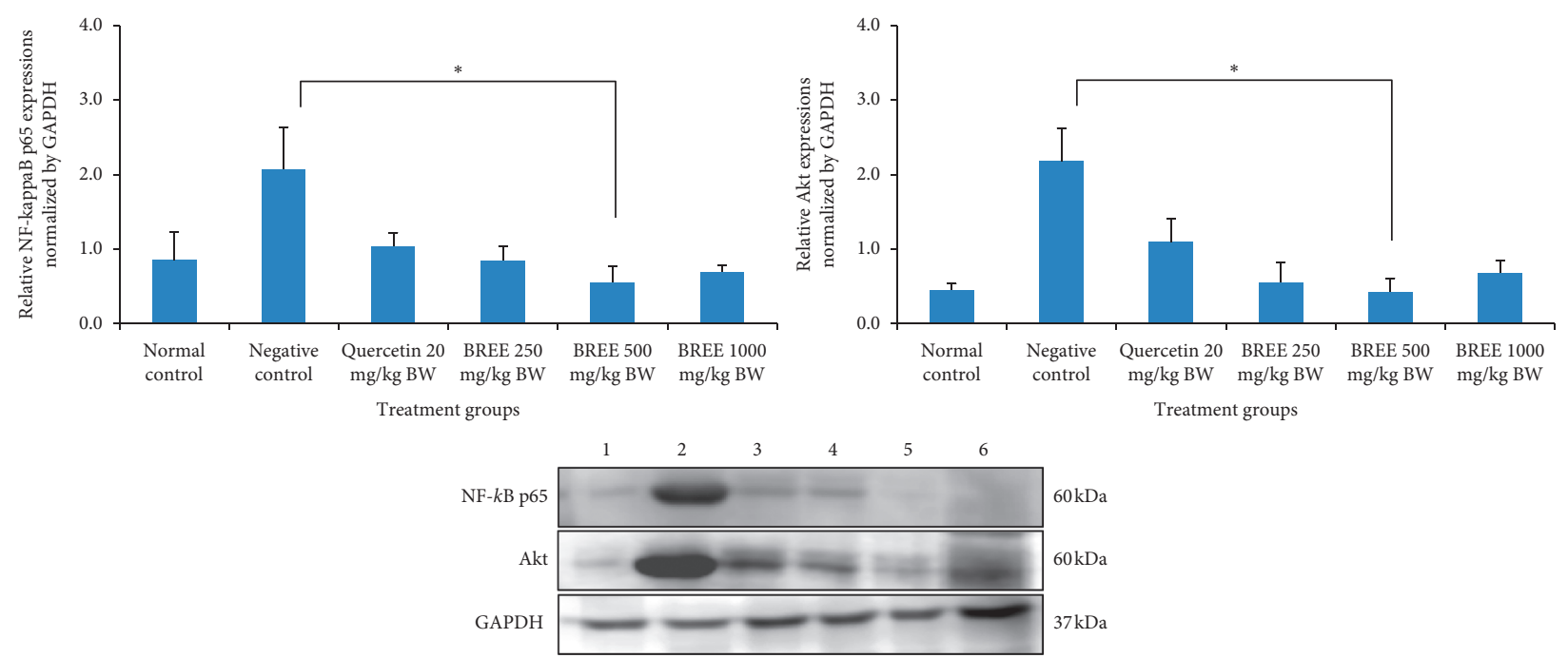

(b)

Figure 6: The bands of NF-kappaB p65 (60 kDa), Akt (60 kDa), and GAPDH (37 kDa) in the stomach (a) and the intestine (b) of the Wistar rats by Western blot analysis. ${ }^{*} p<0.05$ and ${ }^{* *} p<0.01$ means significantly different compared with the normal control (calculated by OneWay ANOVA followed with post hoc Bonferroni test). 1 = Normal, $2=$ Negative Control, $3=$ Quercetin $20 \mathrm{mg} / \mathrm{kg}$ BW, $4=$ BREE $250 \mathrm{mg} /$ $\mathrm{kg} \mathrm{BW}, 5$ = BREE $500 \mathrm{mg} / \mathrm{kg} \mathrm{BW}, 6=$ BREE $1000 \mathrm{mg} / \mathrm{kg} \mathrm{BW}$.

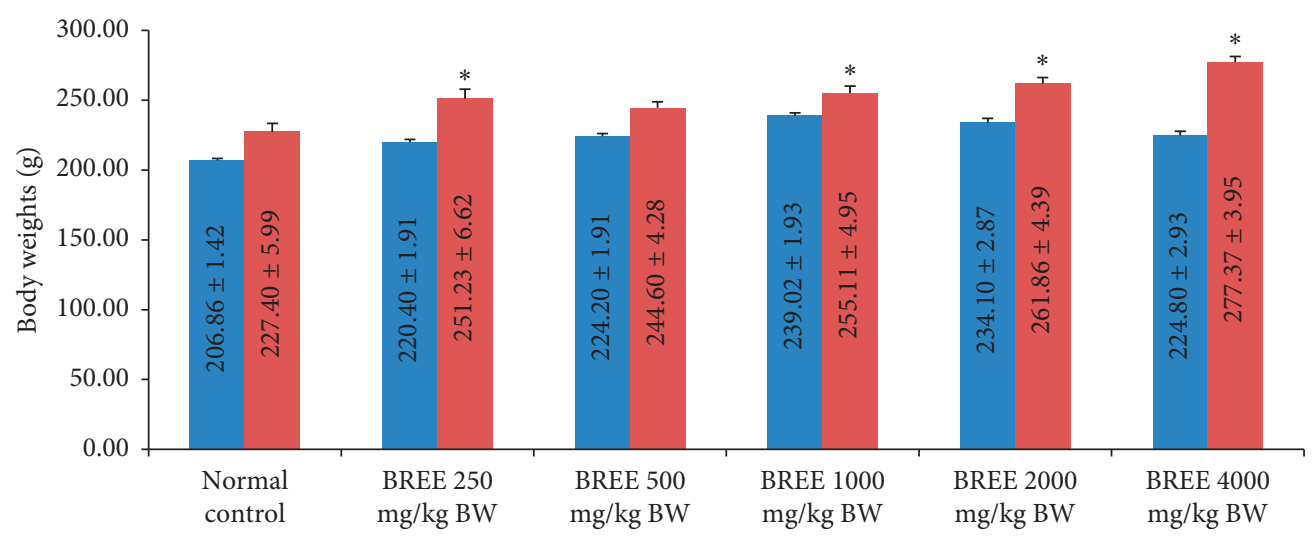

Treatment groups

- D-0 (pre-treatment)

- D-21 (post-treatment)

FIGURE 7: The BW of the rats at D-0 (pre-) and D-21 (post-) BREE treatment. ${ }^{*} p<0.05$ means significantly different compared with the normal control. 


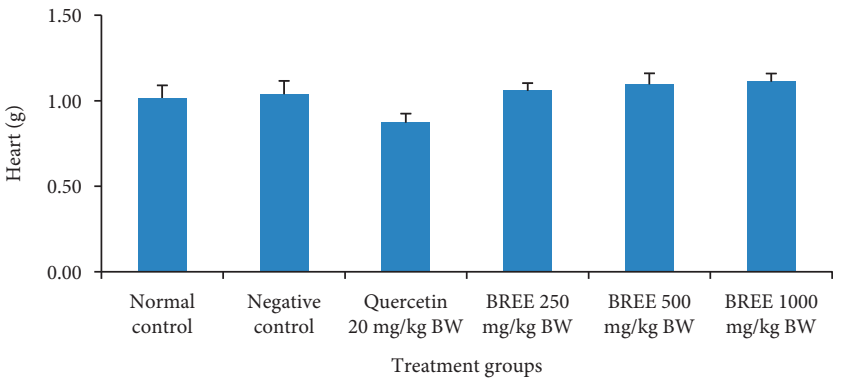

(a)

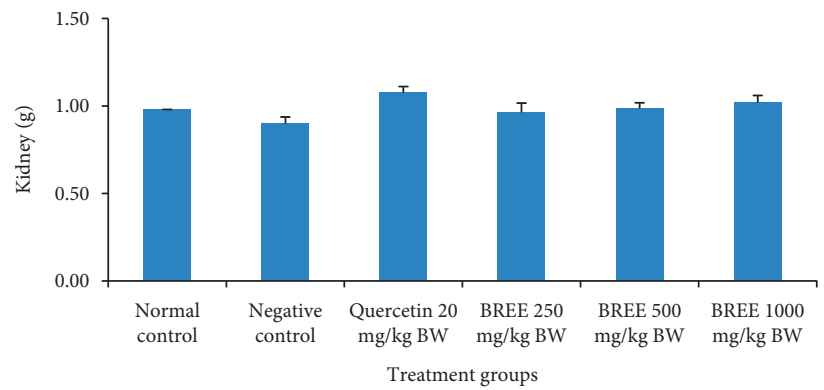

(c)

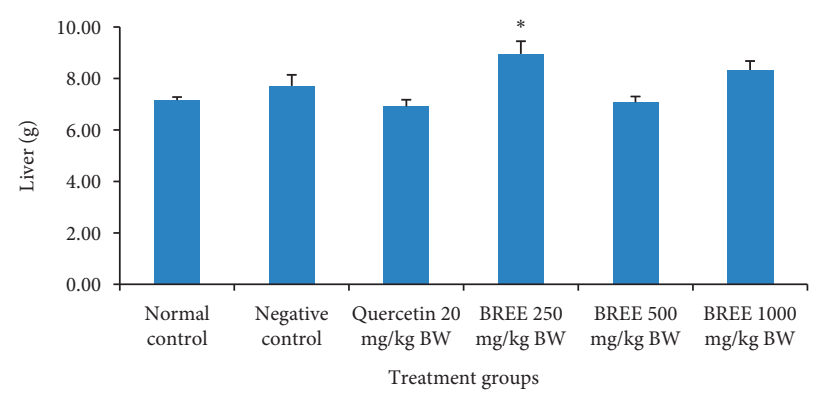

(b)

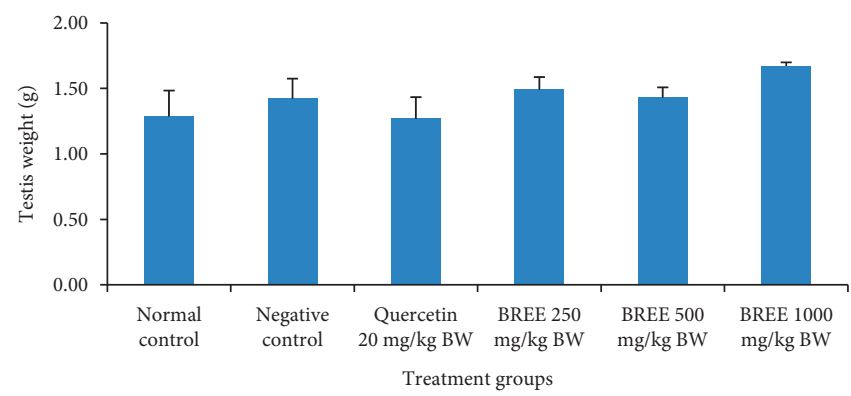

(d)

FIGURE 8: The ratio of organ/BW on day $21^{\text {st }}$ : heart (a); liver (b); kidney (c); testis (d). ${ }^{*}$ indicated $p<0.01(p=0.038)$.
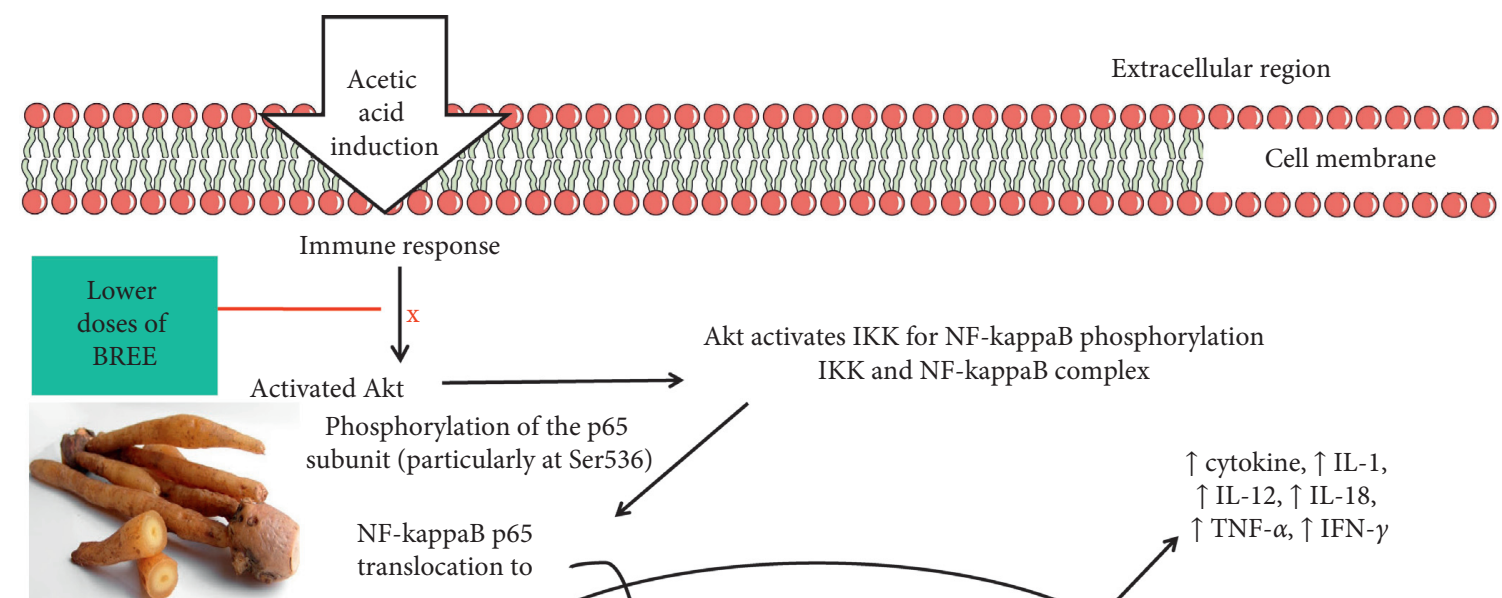

Immune response

Boesenbergia rotunda(L.) Mansf.

Intracellular region

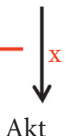

Akt activates IKK for NF-kappaB phosphorylation IKK and NF-kappaB complex

Phosphorylation of the p65

subunit (particularly at Ser536)
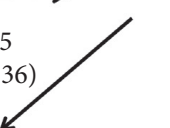

$\uparrow$ cytokine, $\uparrow$ IL- 1

NF-kappaB p65

translocation to

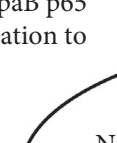

Nucleus

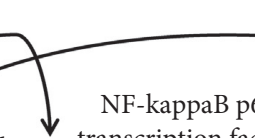

NF-kappaB p65

transcription factor

$\uparrow \mathrm{IL}-12, \uparrow \mathrm{IL}-18$,

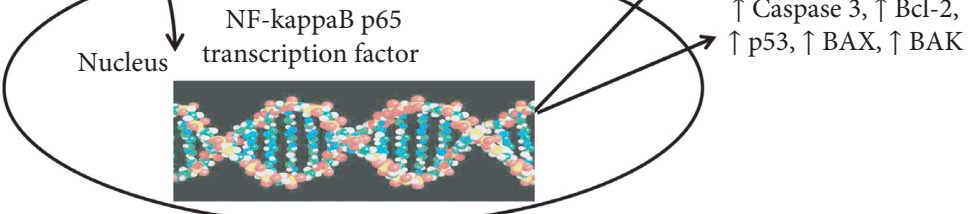

\section{0}

Cell membrane

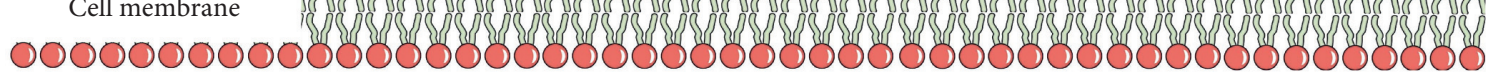

FIGURE 9: Proposed anti-inflammatory mechanism of BREE in acetic acid-induced Wistar rats. Lower doses of BREE (250 mg/kg BW and $500 \mathrm{mg} / \mathrm{kg} \mathrm{BW}$ ) inhibit the activation of Akt thus resulting in the decrease of NF-kappaB p65 in the nucleus.

Taken together, BREE reduces stomach ulceration in rats by inhibiting the activation of Akt; thus the phosphorylation of NF-kappaB p65 at Ser536 is blocked and NF-kappaB p65 could not translocate to the nucleus (Figure 9).
A recent study on the TLR4-dependent activation of NFkappaB in bone marrow-derived and peritoneal primary macrophages indicated that the total amount of cytoplasmic and nucleus NF-kappaB remained unchanged. The NF- 
kappaB level in the nucleus reached its maximum at 10 minutes after lipopolysaccharide induction, then it gradually decreased to a $50 \%$ level at 100 minutes. Nonetheless, the kinetics of NF-kappaB translocation into the nucleus was reported slightly slower than its phosphorylation rate [46].

The main objective of evaluating the safety of any medicinal plant is to identify the nature and significance of toxicity and to establish the exposure level at which this toxicity is observed [47]. Our 21 days of toxicity study indicated that after a single oral BREE treatment, the Wistar rats did not show any sign of toxicity nor death, which indicates that the $\mathrm{LD}_{50}$ of BREE is greater than $4000 \mathrm{mg} /$ $\mathrm{kgBW}$.

The acute toxicity of the $B$. rotunda extract had been evaluated in normal healthy Wistar rats for 72 hours [32] and in Sprague Dawley rats for 14 days [48]. The rats were subjected to a single dose of $2000 \mathrm{mg} / \mathrm{kg} \mathrm{BW} \mathrm{[32]} \mathrm{and}$ $5000 \mathrm{mg} / \mathrm{kg} \mathrm{BW}$ [48] of the rhizome extract preparation, respectively. It was reported that all the rats in this test remained alive and did not manifest mortality or any visible signs of toxicity [32, 48]. The clinical biochemistry measurements of the serum reflected a normal function of the kidney (sodium, potassium, and chloride) and the liver (total bilirubin, alkaline phosphatase, alanine aminotransferase, aspartate aminotransferase, and gamma-glutamyl transferase) [48].

\section{Conclusions}

The peptic-ulceration induced by acetic acid could be inhibited by the ethanol extract of Boesenbergia rotunda (L.) Mansf. rhizome. Specifically, the rhizome of this plant inhibits the activation of Akt thus resulting in a decrease of NF-kappaB p65 expression in the stomach and intestine of acetic acid-induced Wistar rats. Flavonoids contained in the rhizome extract might play a key role in this anti-inflammatory activity. However, this plant still needs further exploration for its potential as plant-based antistomach ulceration.

\section{Data Availability}

The data used to support the findings of this study are included in the article.

\section{Conflicts of Interest}

The authors declare that there are no conflicts of interest regarding the publication of this paper.

\section{Acknowledgments}

The authors would like to thank (1) the Ministry of Research, Technology, and Higher Education, the Republic of Indonesia for funding this research via Doctoral Dissertation Research Grant (No. 1123t/UN6.O/LT/2019) and (2) The Rector of Universitas Padjadjaran for facilitating the publication fee via the Directorate of Research and Community Engagement (DRPM).

\section{References}

[1] M. O. Freire and T. E. Van Dyke, "Natural resolution of inflammation," Periodontol 2000, vol. 63, no. 1, pp. 149-164, 2013.

[2] J. N. Fullerton and D. W. Gilroy, "Resolution of inflammation: a new therapeutic frontier," Nature Reviews Drug Discovery, vol. 15 , no. 8, pp. 551-567, 2016.

[3] K. Matsuzaki, M. Murata, K. Yoshida et al., "Chronic inflammation associated with hepatitis $\mathrm{C}$ virus infection perturbs hepatic transforming growth factor $\beta$ signaling, promoting cirrhosis and hepatocellular carcinoma," Hepatology, vol. 46, no. 1, pp. 48-57, 2007.

[4] H. Yang, H.-J. Ko, J.-Y. Yang et al., "Interleukin-1 promotes coagulation, which is necessary for protective immunity in the lung against streptococcus pneumoniae infection," The Journal of Infectious Diseases, vol. 207, no. 1, pp. 50-60, 2013.

[5] A. Jayaraman, D. Lent-Schochet, and C. J. Pike, "Diet-induced obesity and low testosterone increase neuroinflammation and impair neural function," Journal of Neuroinflammation, vol. 11, no. 1, p. 162, 2014.

[6] M. A. Takhshid, D. Mehrabani, J. Ai, and M. Zarepoor, "The healing effect of licorice extract in acetic acid-induced ulcerative colitis in rat model," Comparative Clinical Pathology, vol. 21, no. 6, pp. 1139-1141, 2012.

[7] S. Z. Farhad, A. Aminzadeh, M. Mafi, M. Barekatain, M. Naghney, and M. R. Ghafari, "The effect of adjunctive lowdose doxycycline and licorice therapy on gingival crevicular fluid matrix metalloproteinase- 8 levels in chronic periodontitis," Dental Research Journal, vol. 10, no. 5, pp. 624-629, 2013.

[8] Q. Li and I. M. Verma, "NF- $\kappa$ B regulation in the immune system," Nature Reviews Immunology, vol. 2, no. 10, pp. 725-734, 2002.

[9] T. Okamoto, T. Sanda, and K. Asamitsu, "NF- $\kappa$ B signaling and carcinogenesis," Current Pharmaceutical Design, vol. 13, no. 5, pp. 447-462, 2007.

[10] T. Liu, L. Zhang, D. Joo, and S.-C. Sun, "NF- $\kappa$ B signaling in inflammation," Signal Transduction and Targeted Therapy, vol. 2, no. 1, pp. 1-9, 2017.

[11] M. Holmes-McNary and A. S. Baldwin, "Chemopreventive properties of trans-resveratrol are associated with inhibition of activation of the I $\kappa$ B kinase," Cancer Research, vol. 60, no. 13, pp. 3477-3483, 2000.

[12] F. Vanini, K. Kashfi, and N. Nath, "The dual role of iNOS in cancer," Redox Biology, vol. 6, pp. 334-343, 2015.

[13] B. Tang, F. Tang, Z. Wang et al., "Upregulation of Akt/Nf- $\kappa \mathrm{B}-$ regulated inflammation and Akt/Bad-related apoptosis signaling pathway involved in hepatic carcinoma process: suppression by carnosic acid nanoparticle," International Journal of Nanomedicine, vol. 11, pp. 6401-6420, 2016.

[14] C. Sostres, C. J. Gargallo, M. T. Arroyo, and A. Lanas, "Adverse effects of non-steroidal anti-inflammatory drugs (NSAIDs, aspirin and coxibs) on upper gastrointestinal tract," Best Practice \& Research Clinical Gastroenterology, vol. 24, no. 2, pp. 121-132, 2010.

[15] H. Buss, A. Dörrie, M. L. Schmitz, E. Hoffmann, K. Resch, and M. Kracht, "Constitutive and interleukin-1-inducible phosphorylation of p65 NF- $\kappa \mathrm{B}$ at serine 536 is mediated by multiple protein kinases including I $\kappa \mathrm{B}$ kinase (IKK)- $\alpha$, IKK $\beta$, IKK $\varepsilon$, TRAF family member-associated (TANK)-binding kinase 1 (TBK1), and an unknown kinase and couples p65 to TATA-binding protein-associated factor II31-mediated 
interleukin-8 transcription," Journal of Biological Chemistry, vol. 279, no. 53, pp. 55633-55643, 2004.

[16] A. Parikh and G. K. Scadding, "Topical nasal lysine aspirin in aspirin-sensitive and aspirin-tolerant chronic rhinosinusitis with nasal polyposis," Expert Review of Clinical Immunology, vol. 10, no. 5, pp. 657-665, 2014.

[17] C. Carrasco-Pozo, R. L. Castillo, C. Beltrán, A. Miranda, J. Fuentes, and M. Gottelend, "Molecular mechanisms of gastrointestinal protection by quercetin against indomethacin-induced damage: role of NF- $\kappa \mathrm{B}$ and Nrf2," The Journal of Nutritional Biochemistry, vol. 27, pp. 289-298, 2016.

[18] D. Krishnaiah, R. Sarbatly, and R. Nithyanandam, "A review of the antioxidant potential of medicinal plant species," Food and Bioproducts Processing, vol. 89, no. 3, pp. 217-233, 2011.

[19] The plant list, Boesenbergia rotunda (L.) Mansf., Kulturpflanze 6, Vol. 236, 1958, http://www.theplantlist.org/tpl/record/kew221874.

[20] S. I. Abdelwahab, S. Mohan, M. A. Abdulla et al., "The methanolic extract of Boesenbergia rotunda (L.) Mansf. and its major compound pinostrobin induces anti-ulcerogenic property in vivo: possible involvement of indirect antioxidant action," Journal of Ethnopharmacology, vol. 137, no. 2, pp. 963-970, 2011.

[21] T. Eng-Chong, L. Yean-Kee, C. Chin-Fei et al., "Boesenbergia rotunda: from ethnomedicine to drug discovery," EvidenceBased Complementary and Alternative Medicine, vol. 2012, Article ID 473637, 25 pages, 2012.

[22] C. H. Hong, S. K. Hur, O.-J. Oh, S. S. Kim, K. A. Nam, and S. K. Lee, "Evaluation of natural products on inhibition of inducible cyclooxygenase (COX-2) and nitric oxide synthase (iNOS) in cultured mouse macrophage cells," Journal of Ethnopharmacology, vol. 83, no. 1-2, pp. 153-159, 2002.

[23] Yanti, Anggakusuma, S.-H. Gwon, and J.-K. Hwang, "Kaempferia pandurata Roxb. inhibits Porphyromonas gingivalis supernatant-induced matrix metalloproteinase- 9 expression via signal transduction in human oral epidermoid cells," Journal of Ethnopharmacology, vol. 123, no. 2, pp. 315-324, 2009.

[24] N. M. Isa, S. I. Abdelwahab, S. Mohan et al., "In vitro antiinflammatory, cytotoxic and antioxidant activities of boesenbergin A, a chalcone isolated from Boesenbergia rotunda (L.) (fingerroot)," Brazilian Journal of Medical and Biological Research, vol. 45, no. 6, pp. 524-530, 2012.

[25] A. Yap, L. Ching, T. S. Wah et al., "Characterization of flavonoid derivatives from Boesenbergia rotunda (L.)," Malaysian Journal of Analytical Sciences, vol. 11, no. 1, pp. 154-159, 2007.

[26] A. A. Mahmood, A. A. Mariod, S. I. Abdelwahab, S. Ismail, and F. Al-Bayaty, "Potential activity of ethanolic extract of Boesenbergia rotunda (L.) rhizomes extract in accelerating wound healing in rats," Journal of Medical Plants Research, vol. 4, pp. 1570-1576, 2010.

[27] S. Okabe and K. Amagase, "An overview of acetic acid ulcer models-the history and state of the art of peptic ulcer research-," Biological \& Pharmaceutical Bulletin, vol. 28, no. 8, pp. 1321-1341, 2005.

[28] S. Taweechaisupapong, S. Singhara, P. Lertsatitthanakorn et al., "Antimicrobial effects of Boesenbergia pandurata and Piper sarmentosum leaf extracts on planktonic cells and biofilm of oral pathogens," Pakistan Journal of Pharmaceutical Sciences, vol. 23, no. 2, pp. 224-231, 2010.

[29] S. W. Woo, D.-B. Rhim, C. Kim, and J.-K. Hwang, "Effect of standardized Boesenbergia pandurata extract and its active compound panduratin A on skin hydration and barrier function in human epidermal keratinocytes," Preventive Nutrition and Food Science, vol. 20, no. 1, pp. 15-21, 2015.

[30] A. G. R. Alkushi and N. A. M. Elsawy, "Quercetin attenuates, indomethacin-induced acute gastric ulcer in rats," Folia Morphologica, vol. 76, no. 2, pp. 252-261, 2017.

[31] D. A. Bardi, M. F. Halabi, N. A. Abdullah, E. Rouhollahi, M. Hajrezaie, and M. A. Abdulla, "In vivo evaluation of ethanolic extract of Zingiber officinale rhizomes for its protective effect against liver cirrhosis," BioMed Research International, vol. 2013, Article ID 918460, 10 pages, 2013.

[32] S. Sini, G. Raj, S. Shyamal, S. Chitra et al., "Safety assessment of tuberous rhizome of Kaempferia rotunda L. by acute and 28-days repeated dose toxicity studies," Global Journal of Pharmacology, vol. 8, pp. 128-139, 2014.

[33] M. Kolgazi, Z. N. Ozdemir-Kumral, C. Cantali-Ozturk et al., "Anti-inflammatory effects of nesfatin-1 on acetic acid-induced gastric ulcer in rats: involvement of cyclo-oxygenase pathway," Journal of Physiology and Pharmacology, vol. 68, no. 5, pp. 765-777, 2017.

[34] C. C. Ozturk, S. Oktay, M. Yuksel, D. Akakin, A. Yarat, and O. K. Cakir, "Anti-inflammatory effects of nesfatin-1 in rats with acetic acid-induced colitis and underlying mechanisms," Journal of Physiology and Pharmacology, vol. 66, no. 5, pp. 741-750, 2015.

[35] G. Cantarella, G. Martinez, V. M. Cutuli et al., "Adrenomedullin modulates COX-2 and HGF expression in reserpine-injuried gastric mucosa in the rat," European Journal of Pharmacology, vol. 518, no. 2-3, pp. 221-226, 2005.

[36] G. Cantarella, G. Martinez, G. D. Benedetto et al., "Protective effects of amylin on reserpine-induced gastric damage in the rat," Pharmacological Research, vol. 56, no. 1, pp. 27-34, 2007.

[37] Q.-W. Zhang, L.-G. Lin, and W.-C. Ye, “Techniques for extraction and isolation of natural products: a comprehensive review," Chinese Medicine, vol. 13, no. 1, p. 20, 2018.

[38] A. M. Rosdianto, I. M. Puspitasari, R. Lesmana, and J. Levita, "Determination of quercetin and flavonol synthase in Boesenbergia rotunda rhizome," Pakistan Journal of Biological Sciences, vol. 23, no. 1, pp. 264-270, 2020.

[39] S. Patel and A. Goyal, "Applications of natural polymer gum Arabic: a review," International Journal of Food Properties, vol. 18, no. 5, pp. 986-998, 2015.

[40] H. Carrie, T. K. Mackey, and S. N. Laird, "Integrating traditional indigenous medicine and western biomedicine into health systems: a review of nicaraguan health policies and miskitu health services," International Journal for Equity in Health, vol. 14, no. 1, p. 129, 2015.

[41] S. Pengpid and K. Peltzer, "Use of traditional medicines and traditional practitioners by children in Indonesia: findings from a national population survey in 2014-2015," Journal of Multidisciplinary Healthcare, vol. 12, pp. 291-298, 2019.

[42] J. Tang, P. Diao, X. Shu, L. Li, and L. Xiong, "Quercetin and quercitrin attenuates the inflammatory response and oxidative stress in LPS-induced RAW264.7 cells: in vitro assessment and a theoretical model," BioMed Research International, vol. 2019, Article ID 7039802, 8 pages, 2019.

[43] T. N. Mayadas, X. Cullere, and C. A. Lowell, "The multifaceted functions of neutrophils," Annual Review of Pathology: Mechanisms of Disease, vol. 9, no. 1, pp. 181-218, 2014.

[44] C. Rosales, "Neutrophil: a cell with many roles in inflammation or several cell types?" Frontiers in Physiology, vol. 9, p. 113, 2018.

[45] M. Bertocchi, G. Isani, F. Medici et al., "Anti-inflammatory activity of Boswellia serrata extracts: an in vitro study on porcine aortic endothelial cells," Oxidative Medicine and 
Cellular Longevity, vol. 2018, Article ID 2504305, 9 pages, 2018.

[46] A. V. Bagaev, A. Y. Garaeva, E. S. Lebedeva, A. V. Pichugin, R. I. Ataullakhanov, and F. I. Ataullakhanov, "Elevated preactivation basal level of nuclear NF- $\kappa \mathrm{B}$ in native macrophages accelerates LPS-induced translocation of cytosolic NF- $\kappa$ B into the cell nucleus," Scientific Reports, vol. 9, no. 1, 2019.

[47] M. B. Ibrahim, A. A. Sowemimo, M. O. Sofidiya et al., "Subacute and chronic toxicity profiles of Markhamia tomentos a ethanolic leaf extract in rats," Journal of Ethnopharmacology, vol. 193, pp. 68-75, 2016.

[48] S. M. Salama, M. Bilgen, A. S. Al Rashdi, and M. A. Abdulla, "Efficacy of Boesenbergia rotunda treatment against thioacetamide-induced liver cirrhosis in a rat model," EvidenceBased Complementary and Alternative Medicine, vol. 2012, Article ID 137083, 12 pages, 2012. 